\title{
(6) OPEN ACCESS \\ Beyond excise taxes: a systematic review of literature on non-tax policy approaches to raising tobacco product prices
}

\author{
Shelley D Golden, ${ }^{1}$ Margaret Holt Smith, ${ }^{1,2}$ Ellen C Feighery, ${ }^{3}$ April Roeseler, ${ }^{4}$ \\ Todd Rogers, ${ }^{5}$ Kurt M Ribis| ${ }^{1,2}$
}

- Additional material is published online only. To view please visit the journal online (http://dx.doi.org/10.1136/ tobaccocontrol-2015-052294).

${ }^{1}$ Gillings School of Global Public Health, University of North Carolina, Chapel Hill, North Carolina, USA ${ }^{2}$ Lineberger Comprehensive Cancer Center, University of North Carolina, Chapel Hill, North Carolina, USA ${ }^{3}$ International Research, Campaign for Tobacco Free Kids, Washington DC, USA ${ }^{4}$ California Department of Public Health, California Tobacco Control Program, Sacramento, California, USA ${ }^{5}$ Public Health Research Division, RTI International, San Francisco, California, USA

\section{Correspondence to}

Dr Shelley D Golden, Department of Health Behavior, Gillings School of Global Public Health, University of North Carolina, 364 Rosenau Hall, CB7440, Chapel Hill, NC 27599, UK shelley_golden@unc.edu

Received 19 February 2015 Revised 15 June 2015 Accepted 2 July 2015 Published Online First 21 September 2015

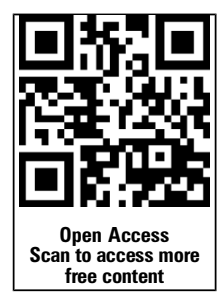

CrossMark

To cite: Golden SD, Smith MH, Feighery EC, et al. Tob Control 2016;25:377-385.

\section{ABSTRACT}

Objective Raising the price of tobacco products is considered one of the most effective ways to reduce tobacco use. In addition to excise taxes, governments are exploring other policies to raise tobacco prices and minimise price dispersion, both within and across price tiers. We conducted a systematic review to determine how these policies are described, recommended and evaluated in the literature.

Data sources We systematically searched six databases and the California Tobacco Control library for English language studies or reports, indexed on or before 18 December 2013, that included a tobacco keyword (eg, cigarette), policy keyword (eg, legislation) and a price keyword (eg, promotion). We identified 3067 abstracts. Study selection Two coders independently reviewed all abstracts and identified 56 studies or reports that explicitly described a public policy likely to impact the retail price of tobacco products through non-tax means.

Data extraction Two coders independently identified tobacco products targeted by policies described, recommendations for implementing policies and empirical assessments of policy impacts.

Data synthesis The most prevalent non-tax price policies were price promotion restrictions and minimum price laws. Few studies measured the impact of non-tax policies on average prices, price dispersion or disparities in tobacco consumption, but the literature includes suggestions for crafting policies and preparing for legal challenges or tobacco industry opposition.

Conclusions Price-focused evaluations of wellimplemented non-tax price policies are needed to determine whether they can deliver on their promise to raise prices, reduce price dispersion and serve as an important complement to excise taxes.

\section{INTRODUCTION}

Raising the price of tobacco products is considered one of the most effective ways to reduce consumption $^{1-3}$ and is a highly recommended tobacco control strategy worldwide. ${ }^{4} 5$ Although excise taxes have effectively raised average product prices in many jurisdictions, additional policies that rely on mechanisms other than taxation may be needed to maintain higher prices and prevent price discrimination resulting in lower prices for pricesensitive smokers. ${ }^{6-8}$

Countries all over the world have used tobacco taxes to increase prices and reduce consumption, ${ }^{9}$ but not all tax initiatives are equally successful. The tobacco industry works to defeat or limit proposed increases through lobbying and other tactics, ${ }^{10}$ and in many places other political barriers exist, resulting in tax and price geographic variation. ${ }^{11}{ }^{12}$ In the USA in 2014, average prices for a pack of cigarettes ranged from US\$5.06 in Missouri, where the lowest excise tax is levied, to $\$ 10.56$ in New York, home of the highest. ${ }^{13}$ The structure of a tax is also relevant. Tax structures that rely primarily on ad valorem approaches, which tax based on a per cent of product value, may have weaker health impacts by facilitating substitution to cheaper brands, ${ }^{14}{ }^{15}$ compared to specific taxes, which are levied on a specific quantity and therefore impact all brands equally. Specific taxes that are not indexed to inflation, however, devalue over time. ${ }^{10-16}$

Even when well-structured high taxes are successfully implemented, tobacco companies engage in price discrimination to offset their effects. Price discrimination is the process by which firms with monopoly power segment their market and set lower prices for those consumers who are most price-sensitive. ${ }^{17}$ Tobacco companies accomplish this by offering select retailers and consumers price promotions, including volume-based discounts, multipack offers and coupons, ${ }^{18-23}$ and by providing products in different price tiers, including higher priced 'premium' products and lower priced 'discount' products. ${ }^{24} 25$ This produces a cigarette market characterised by price dispersion, both within and between price tiers.

As tobacco taxes rise, incentives for the industry to engage in price discrimination to avoid losing price sensitive customers increase. In the US alone, dollars spent on cigarette advertising and promotion rose from $\$ 8.37$ billion in 2011 to $\$ 9.17$ billion in 2012. Price discounts has been the largest marketing expenditure category since 2002, and in 2012 it accounted for more than $85 \%$ of marketing spending by the industry. ${ }^{26}$ In some places, price gaps between premium and discount price tiers have gotten larger as well, possibly due to disproportionate shifting of tax increases to higher priced brand variants to maintain options for price sensitive customers. $^{27} 28$ Elsewhere, however, this pattern appears reversed, perhaps due to extensive price promotions for premium brands. ${ }^{29} 30$

Tobacco users respond to opportunities to purchase lower priced products. ${ }^{31}$ In various surveys, between $25 \%$ and $40 \%$ of respondents report using discounts and/or cheaper brands. Several US studies found that purchasing cheaper brands, or buying with a discount or multipack offer, was associated with price reductions of up to $\$ 1$ per pack. ${ }^{32-35}$ 
People who engage in price-minimising strategies make fewer cessation attempts and are less likely to reduce their smoking. ${ }^{36-38}$

Some of the highest risk groups for tobacco initiation and use, including youth and people with lower incomes, ${ }^{39-42}$ are also the most price sensitive, so price dispersion may be a particularly important policy target. Furthermore, groups engage in different price minimisation strategies, so understanding whether a policy is likely to change average prices, prices within a specific price tier, or the availability of low price tiers, is important for understanding potential impacts on vulnerable populations. For example, more than one-third of youth smokers report exposure to price coupons ${ }^{43}$ and young adults are both more likely to use coupons or promotions, and less likely to smoke discount brands, compared to older smokers. ${ }^{44}{ }^{45}$ Policies that shrink tier-specific price dispersion may therefore have a particularly strong impact on youth. Lower income smokers, however, are more likely to buy discount brands, 293745 so policies that target low price tiers might ameliorate socioeconomic disparities in smoking.

To boost prices in low tax areas and counteract tobacco industry price reduction strategies, many governments are exploring policies to increase tobacco prices through mechanisms other than taxation, including setting minimum prices or banning promotional discounts. Although the impact of tobacco tax policies has been previously summarised, ${ }^{10}{ }^{14}$ the practical and substantive advantages and disadvantages of other price policy options have not been similarly explored. To fill this gap, we conducted a systematic review of the literature to determine how non-tax tobacco price policies are described, recommended and evaluated.

\section{METHODS}

\section{Data sources}

We searched six databases of peer-reviewed literature (PubMed, CINAHL, EMBASE, Scopus, Academic Search Premier and Legal Trac), and ROVER, a grey literature library maintained by California's Tobacco Control Library. We identified studies and reports that contained one tobacco-related word (cigarette* or tobacco*), one policy-related term (eg, 'public policy' or 'law') and one price-related term (eg, 'promotion,' or 'discount'). After eliminating duplicates, this search produced 3067 abstracts.

\section{Study selection}

Two coders independently reviewed all English language abstracts or full text publications that described, analysed or discussed a public policy likely to directly impact retail tobacco prices through means other than taxation. We initially excluded 2824 abstracts that failed to reference any price-relevant tobacco control policy, and an additional 187 articles that focused on policies outside the scope of this review, described potential price-related policies but made no explicit mention of price impacts, were not an appropriate format (eg, news reports), or were not in English. Following these exclusions, 56 articles (35 peer-reviewed studies and 21 reports) were included in the review (figure 1).

\section{Data extraction}

One of two authors (SDG and MHS) read each article to extract: publication year, policies described, geographic location in which policies were considered, targeted tobacco product, any empirical policy evaluation results, and other key findings or conclusions. Each article was then read by the second reviewer to collect information around three key themes: (1)

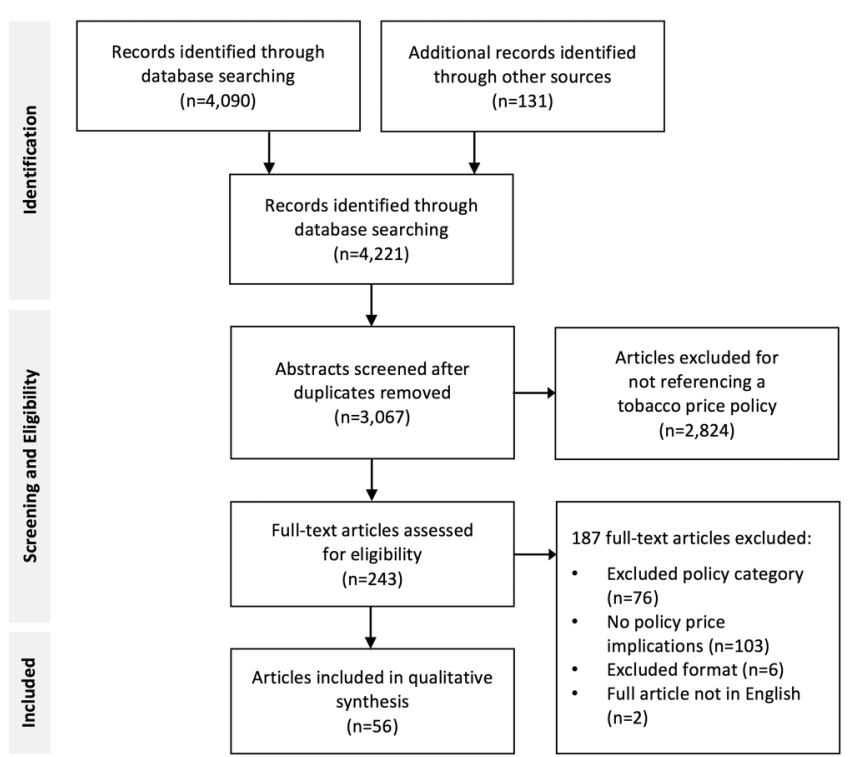

Figure 1 Process of study selection.

policy justification; (2) policy descriptions and recommendations; and (3) potential impacts of policies on price, consumption or disparities.

\section{Data synthesis}

We calculated frequency measures for the policy types, locations and targeted products, and then summarised the key theme data using principles of qualitative analysis. ${ }^{46}$ Given the paucity of empirical evaluations and heterogeneous policy types and outcomes, we were prevented from conducting a meta-analysis. Instead, we summarise the findings of each policy evaluation individually.

\section{RESULTS}

With the exception of a 1986 article describing the potential for advertising bans to impact product prices, ${ }^{47}$ all non-tax policy articles in this review were published in 1999 or later, and 71\% $(n=40)$ were published since 2010 (figure 2). Non-tax policies were discussed with similar and increasing frequency in the US and global contexts. Reviewed articles described a variety of non-tax price policies, including price promotion restrictions $(n=41)$, minimum price policies $(n=27)$, fee-based policies $(n=6)$ and price capping laws $(n=4$; see online supplementary figure). These policies are defined in table 1. Price-relevant aspects of other policies, such as sunshine laws, which require reporting of industry price discounting and promotional payments, ${ }^{48}$ were mentioned but not substantially discussed in five articles. The majority of articles described policies specifically targeting cigarettes $(n=48)$ or all tobacco products $(n=33)$. A small number of articles addressed policies related specifically to cigars $(n=2)$, smokeless $(n=2)$, other tobacco products $(n=4)$ or electronic cigarettes $(n=1)$.

\section{Policy justification}

Almost half of the articles $(n=29,48 \%)$ elaborated on reasons that non-tax tobacco price policies are needed. In most of these $(n=22)$, evidence of industry efforts to keep prices low through advertising and price promotions, ${ }^{11} 364749-53$ price setting ${ }^{54}$ or antiprice policy lobbying ${ }^{55}$ was used as a rationale, with some emphasis on disproportionate targeting and tobacco use among youth, African-Americans and residents of neighbourhoods with 


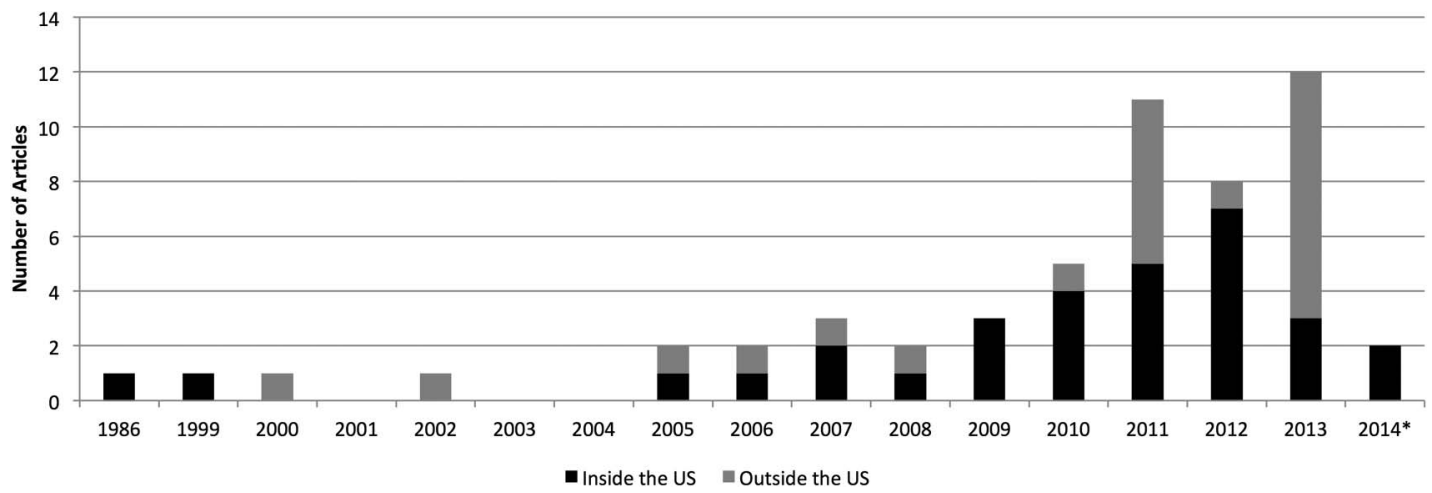

Figure 2 Article describing non-tax price policies identified in systematic review by publication year and location $(n=56)$.

higher percentages of price-sensitive smokers. ${ }^{56-59}$ A few articles analysed or cited evidence of public support for price-related policies, ${ }^{60} 61$ identified other policy benefits, like offsetting tobacco-related public costs, ${ }^{62-64}$ or referenced similar policies implemented for other products. ${ }^{54} 65$ Finally, several authors identified gaps in existing legislation that needed to be filled. ${ }^{5366}$

\section{Policy descriptions, recommendations, political factors} and legal issues

Regardless of policy type, more than one-quarter of the articles $(n=15)$ recommended combining non-tax price policies with taxes to prevent the use of price minimising strategies. Nearly half of all articles $(n=26)$ described political or legal issues related to price-related policies, including: tobacco industry opposition to, or efforts to circumvent, price-related policies; the importance of considering rules related to commerce, free speech and policy pre-emption by a higher level of government; the value of consulting legal counsel in legislation design; and concerns about the implications of price policies for low income consumers. Recommendations, political factors and legal concerns specific to each of the most cited non-tax policy types are outlined in table 1 , and summarised below.

Table 1 Non-tax price policies, recommendations and legal considerations described in the literature

\begin{tabular}{|c|c|c|c|}
\hline Policy & General description & Recommendations & Political arguments and legal considerations \\
\hline $\begin{array}{l}\text { Restrictions on } \\
\text { price } \\
\text { promotions }\end{array}$ & $\begin{array}{l}\text { Bans or restrictions on tobacco product coupons, } \\
\text { value-added promotions (eg, 'buy one get one' } \\
\text { offers), or retailer rebates (eg, buy-down } \\
\text { programmes) }\end{array}$ & $\begin{array}{l}\text { Create comprehensive, rather than } \\
\text { partial marketing bans and explicitly } \\
\text { include price promotion restrictions. } \\
\text { Sufficiently enforce implemented price } \\
\text { promotion restrictions. Consider tying } \\
\text { adherence to licensing, where } \\
\text { appropriate. } \\
\text { Ensure promotional bans apply only } \\
\text { within the jurisdiction in which the law } \\
\text { is passed }\end{array}$ & $\begin{array}{l}\text { Anticipate industry resistance to any promotional } \\
\text { restrictions } \\
\text { In the USA, any impact on interstate commerce } \\
\text { must be offset by benefit to state or locality } \\
\text { In the USA, states and localities can only restrict } \\
\text { the time, place and manner, but not the content, } \\
\text { of promotion } \\
\text { In the USA, banning coupon redemption rather } \\
\text { than distribution may be less likely to inhibit } \\
\text { interstate commerce }\end{array}$ \\
\hline $\begin{array}{l}\text { Minimum price } \\
\text { laws }\end{array}$ & $\begin{array}{l}\text { Laws that require a per cent mark-up on the } \\
\text { wholesale/retail price of a tobacco product and/or } \\
\text { a minimum floor price beneath which product } \\
\text { cannot be sold }\end{array}$ & $\begin{array}{l}\text { Consider a floor price structure } \\
\text { Remove provisions that allow discounts, } \\
\text { coupons, buy-downs } \\
\text { Set rates above those established by } \\
\text { free market } \\
\text { Impose strong penalties and dedicate } \\
\text { more resources for enforcement. } \\
\text { Extend to non-cigarette tobacco } \\
\text { products }\end{array}$ & $\begin{array}{l}\text { Might be politically feasible in places where } \\
\text { higher excise taxes are not. } \\
\text { Draft laws to impact retailers in different } \\
\text { jurisdictions equally and to avoid price fixing. } \\
\text { Could benefit the tobacco industry and do not } \\
\text { raise money for tobacco control efforts }\end{array}$ \\
\hline $\begin{array}{l}\text { Fee-based } \\
\text { policies }\end{array}$ & $\begin{array}{l}\text { Laws applying a fee to tobacco products to offset } \\
\text { costs incurred by government related to } \\
\text { tobacco-related issues, including improperly } \\
\text { disposed cigarette butts/waste, and managing } \\
\text { retailer licensing programmes }\end{array}$ & $\begin{array}{l}\text { Base fee level on demonstrable costs } \\
\text { Raised monies must be allocated to } \\
\text { programme costs (eg, litter clean-up } \\
\text { efforts, licensing programme } \\
\text { administration) } \\
\text { To impact prices, fees may need to be } \\
\text { substantial }\end{array}$ & $\begin{array}{l}\text { In some places, local laws may be pre-empted by } \\
\text { laws from a higher level jurisdiction (eg, state or } \\
\text { federal) } \\
\text { In addition to impacting price, mitigation fees } \\
\text { offset government costs for cleanup and result in } \\
\text { less toxic environments. One study found that } \\
\text { cigarette litter accounted for nearly } 1 / 4 \text { of all } \\
\text { waste-related costs }\end{array}$ \\
\hline Price capping & $\begin{array}{l}\text { Laws that place a cap on the pretax manufacturers' } \\
\text { price }\end{array}$ & $\begin{array}{l}\text { Base cap level on costs faced by firms } \\
\text { Pair with high excise taxes to transfer } \\
\text { industry profits to government revenue } \\
\text { and promote tobacco control } \\
\text { Pair with marketing restrictions to } \\
\text { inhibit targeted promotional discounts } \\
\text { in new markets }\end{array}$ & $\begin{array}{l}\text { Can be justified to counter excess market power } \\
\text { by few large tobacco companies } \\
\text { Not well implemented for tobacco products, but } \\
\text { has been used in utilities }\end{array}$ \\
\hline
\end{tabular}


Price promotion restrictions and bans

The review highlighted two different strategies for restricting the ability of tobacco companies, wholesalers or retailers to use price promotions to reduce tobacco prices: comprehensive tobacco marketing legislation that includes price promotion restrictions or standalone legislation restricting price promotions only. Specific price promotion policy components include banning or restricting: tobacco product coupons; valueadded promotions like multipack discounting or cross-product promotions; and/or buy-down or master-type programmes in which manufacturers offer price discounts to retailers or wholesalers.

Nearly all of the articles discussing price promotions as part of comprehensive marketing bans reference Article 13 of the WHO's Framework Convention on Tobacco Control, which recommends marketing bans on both direct and indirect advertising, including the distribution of promotional discounts. ${ }^{4} 67$ Several authors argued that few countries implement truly comprehensive marketing bans, often because the bans fail to include point-of-sale or price promotion bans. ${ }^{68-70}$ Throughout the marketing ban papers, authors noted the importance of implementing comprehensive bans to ensure advertising opportunities were not simply moved to different channels following partial bans. ${ }^{71-74}$ For example, Moodie et al ${ }^{75}$ documented an increase in pack-based marketing, including price-related offers on the pack, following the passage of the British Tobacco Advertising and Promotion Act which eliminated many other forms of marketing. In addition to moving into new marketing venues, authors cautioned that the tobacco industry would maximise marketing where restrictions are non-existent, work to weaken any marketing regulation that is introduced and use cross-border advertising to their advantage. ${ }^{72}$

Stand-alone price promotion policies were primarily discussed in the USA, where the 2009 Family Smoking Prevention and Tobacco Control Act (TCA) bans redemption of coupons by mail, but does not address the use of promotions in the retail setting. ${ }^{36}$ The TCA permits state and local governments to regulate the sale and distribution of tobacco products, and also amended earlier legislation to allow states and localities to regulate the time, place and manner, ${ }^{76}$ but not the content, of cigarette advertisements or promotions. Although two reports highlighted successful implementations of city policies, ${ }^{57} 77$ most of the US price promotion literature investigated potential legal barriers and offered recommendations for legally defensible legislation. State and local governments were cautioned to limit burden on interstate commerce, and ensure their legislation does not go beyond legislation at higher levels of government. ${ }^{57} 78$ To maximise legal viability, authors recommended restricting advertising only within a specific jurisdiction, banning the redemption of coupons rather than their distribution and targeting actual price reductions rather than specific advertising messages. ${ }^{49} 5153577879$ In places where tobacco licenses are issued, adherence to price promotion rules could be tied to licensing maintenance ${ }^{50} 80$ or restrictions on price promotions could be added to existing minimum price legislation. ${ }^{53} 8182$

\section{Minimum price policies}

Minimum price laws (MPLs), originally implemented to protect tobacco retailers from predatory business practices, ${ }^{11} 82$ establish a minimum mark-up on the retail and/or wholesale price of a tobacco product. Most literature on this topic came from the US, where MPLs operate in about half of all states by levying a per cent mark-up on a basic cost price. ${ }^{82}$ To eliminate discount brands from the market, and for ease of administration, several authors recommended a floor price structure, which sets a level below which a product cannot be sold or a combination of a floor price with either mark-ups ${ }^{50} 58$ or price capping policies. ${ }^{56}$ In addition, three strategies to enhance the impact of MPLs were suggested: (1) eliminate the use of coupons, buy-downs or other promotional strategies to lower prices below minimum

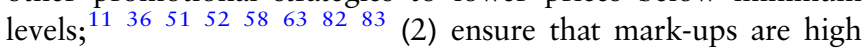
enough to result in prices above those determined naturally by the market by setting high initial rates and indexing them to inflation; 52588384 and (3) impose strong penalties for violation and provide resources for enforcement. ${ }^{83} 85$

MPLs were recognised as strategies that could complement high excise taxes, or be more politically palatable in places where raising excise taxes has been difficult. ${ }^{63}$ Authors cautioned, however, that MPLs may be challenged as infringing too much on free market competition ${ }^{52} 86$ or interstate commerce. ${ }^{52}$ To prevent such attacks, legislation should be drafted in a way to stave off accusations of price fixing and to ensure that retailers within and outside of the jurisdictional area are treated the same way. ${ }^{515263}$ Several authors also noted additional potential consequences of MPLs, including increasing profits for the tobacco industry and retailers in the place of increased revenue from excise taxes, ${ }^{50} 5683858788$ providing a basis for marketing products as sold at the 'minimum legal price, ${ }^{, 83}$ or encouraging cross-border purchasing if implemented irregularly. ${ }^{11}$

\section{Fee-based policies}

Although fees are similar to taxes because the amount added to the price returns to government, we include them in our review as distinct from taxes for two reasons. First, the funds raised by fees cannot exceed the costs of implementing the services to which they are attached; their allowable size must be determined through careful analysis. Second, fees are a policy option available in some local communities that do not inherently have taxing authority. Articles in this review described two types of fees: mitigation and licensing fees. Cigarette butts are a common type of litter ${ }^{89}$ that creates chemical hazards in public spaces and incurs governmental costs for removal. Mitigation fee policies levy per-pack fees to offset these costs and eliminate some waste by-products. Two articles specifically described the process and results of calculating the San Francisco litter abatement policy; the author estimated that cleaning up cigarette litter costs about 22 cents per pack, ${ }^{64}{ }^{90}$ but also noted that cities could use national or comparable place figures to calculate appropriate fees. Licensing fees are charged to retailers to fund the administration of retailer licensing programmes. Although the initial search generated many articles describing licensing fees, only two explicitly described the the potential impact on product prices. Authors noted that substantial fee increases (perhaps beyond what is justifiable in terms of costs) might be needed to raise prices, ${ }^{63}$ and that indexing fees to inflation or product prices could ensure they are sustained at relatively high levels. $^{62}$

\section{Price caps}

Four articles describe or propose price capping policies, which set limits on the maximum price level that the industry can charge for a product. By setting price caps close to the level of production costs, authors argue that the large companies that currently dominate the market will no longer be able to target specific audiences with low prices, because they cannot make up the profit loss through higher prices on other products or in 
other venues. Implemented by itself a price cap would then compress prices, but might actually lower average product prices. Supporters of price caps therefore recommend pairing them with high excise taxes. ${ }^{545691}$ In this way, product sales generate 'profits' that are realised by the government, rather than by the manufacturers or retailers.

\section{Policy impacts}

Although most of the articles discussed the potential of non-tax price policies to reduce tobacco prices, consumption and/or related health problems $(n=46,77 \%)$, only 16 articles $(27 \%)$ empirically examined policy impacts. Nine of these measured the effect of a policy package without specifying outcomes for price-related components. For example, seven articles used the SimSmoke model to evaluate or predict the impact of different recommended tobacco control strategies, including comprehensive marketing bans, but did not isolate the effect of price promotion restrictions within those bans. The remaining six empirical impact articles explicitly assessed the impact of either MPLs or price promotion restrictions a relevant outcome. $^{11} 126873748392$ Of them, three cross-national comparisons documented positive associations between stronger price promotion restrictions policies and decreased awareness of promotional offers, two found no evidence that average cigarette prices were higher in places that had implemented MPLs, and one found no average price impacts of a voluntary, industry-led policy. Findings of each article are further described in table 2.

\section{DISCUSSION}

Policies targeting tobacco prices through mechanisms other than taxes are gaining attention in the literature. The articles reviewed here provide detailed definitions of price promotion bans, minimum price legislation and other policies, as well as suggestions for making them as strong and legally robust as possible. Policymakers or practitioners interested in exploring these options, therefore, have resources that could guide policy development. Given the economic and legal complexities outlined in many of the reviewed works, as well as industry and political challenges faced by most tobacco control legislation, ${ }^{49} 51525878$ this guidance may be necessary before adoption and sustained implementation of any price-focused policies is commonplace.

Infrequent in the literature, however, are assessments of the effectiveness of non-tax price policies as tobacco control strategies. Associations between higher tobacco prices and lower levels of tobacco consumption are already well established; ${ }^{1-3}$ what is not yet known is whether other policies can bring about average price increases through means other than tax hikes. Our search generated a small number of empirical assessments which failed to isolate price effects; measured only proximal outcomes like promotion awareness, or found no evidence that policies successfully raised average cigarette prices.

Furthermore, we found little discussion and no evaluation of the potential impact of the reviewed policies on price dispersion, either within or between price tiers. Yet several of these policies may prove particularly useful in shrinking price dispersion, eliminating opportunities for the industry to leverage differential profit margins to target marketing or offer discount brands to price-sensitive smokers. More specifically, policies that reduce price dispersion within price tiers may particularly impact those smokers who are brand loyal, but frequently exposed to coupons, like youth, whereas policies that reduce price dispersion between price tiers could reduce consumption among groups currently using deep discount brands, like low income smokers. Understanding whether a policy impacts price dispersion and how it does so, is therefore critical to predicting the impact of that policy on vulnerable populations, another topic that received little attention in the reviewed literature. More rigorous evaluation is needed to identify the impact of reviewed policies on average prices, as well as price dispersion and tobacco use among price sensitive groups.

To support such endeavours, we hypothesise potential mechanisms through which non-tax policies might influence average prices and price dispersion, both within and between price tiers and illustrate these in figure 3. In the first panel, which represents an initial cigarette market, the black line tracks

Table 2 Articles that empirically assess non-tax price policies

\begin{tabular}{|c|c|c|c|c|}
\hline Year & $\begin{array}{l}\text { First } \\
\text { author }\end{array}$ & Location & Outcome measure & Price-related article findings \\
\hline \multicolumn{5}{|c|}{ Minimum price laws (MPLs) } \\
\hline 2005 & Feighery ${ }^{11}$ & USA & Cigarette prices & $\begin{array}{l}\text { Prices in states with MPLs were not significantly lower than prices in states without, but } \\
\text { were higher in NY, the one MPL state that prohibited special price promotions }\end{array}$ \\
\hline 2012 & Tynan $^{83}$ & USA & Cigarette prices & $\begin{array}{l}\text { Prices were lower in states with MPLs than in states without them. This finding was } \\
\text { consistent in the grocery channel ( } 46 \text { cents difference), drug channel ( } 29 \text { cents difference) } \\
\text { and convenience stores ( } 13 \text { cents difference) }\end{array}$ \\
\hline \multicolumn{5}{|c|}{ Price promotion restrictions } \\
\hline 2006 & Harris $^{73}$ & $\begin{array}{l}\text { UK, USA, Canada, } \\
\text { Australia }\end{array}$ & $\begin{array}{l}\text { Awareness of promotions } \\
\text { (2002 and 2003) }\end{array}$ & $\begin{array}{l}\text { Awareness of special price promotions declined from } 62 \% \text { to } 46 \% \text { in the UK in the year } \\
\text { following a ban on special price promotions. This change was greater than changes } \\
\text { occurring during the same time period in three countries that did not implement a ban }\end{array}$ \\
\hline 2008 & Yong $^{74}$ & $\begin{array}{l}\text { Malaysia, } \\
\text { Thailand }\end{array}$ & Awareness of promotions & $\begin{array}{l}\text { In two countries that have implemented similar marketing bans, } 21.6 \% \text { of respondents in } \\
\text { the country that does not enforce the ban (Malaysia) reported seeing special price offers, } \\
\text { compared to only } 2.5 \% \text { of smokers in the country that does enforce the ban (Thailand) }\end{array}$ \\
\hline 2009 & Feighery $^{12}$ & USA & $\begin{array}{l}\text { Brand-specific price and } \\
\text { promotions in stores }\end{array}$ & $\begin{array}{l}\text { There were no differences in prices or promotions for Phillip Morris USA cigarette brands in } \\
\text { stores where promotions were suspended by the company compared to stores that had not } \\
\text { been sanctioned }\end{array}$ \\
\hline 2011 & Kasza $^{68}$ & $\begin{array}{l}\text { UK, USA, Canada, } \\
\text { Australia }\end{array}$ & $\begin{array}{l}\text { Awareness of promotions } \\
\text { (2002 and 2008) }\end{array}$ & $\begin{array}{l}\text { Awareness of price promotions declined from } 62 \% \text { to } 25 \% \text { in the UK following the } \\
\text { implementation on a ban on special price promotions. This change was greater than } \\
\text { changes occurring during the same time period in three countries that did not implement a } \\
\text { ban }\end{array}$ \\
\hline
\end{tabular}




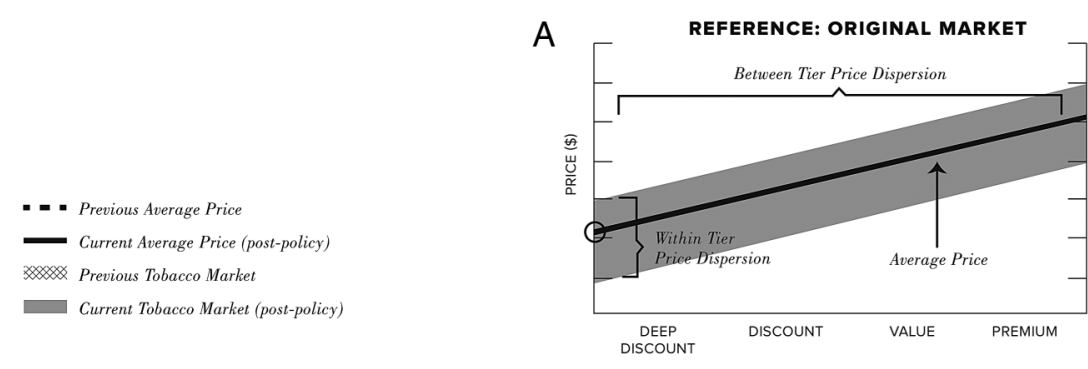

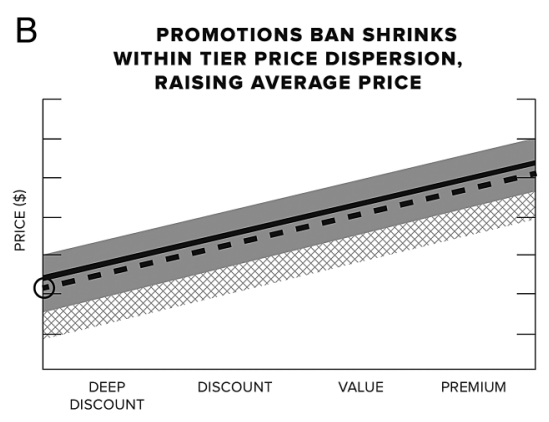
FLOOR MPL REDUCES BETWEEN
TIER PRICE DISPERSION, ELIMINATING
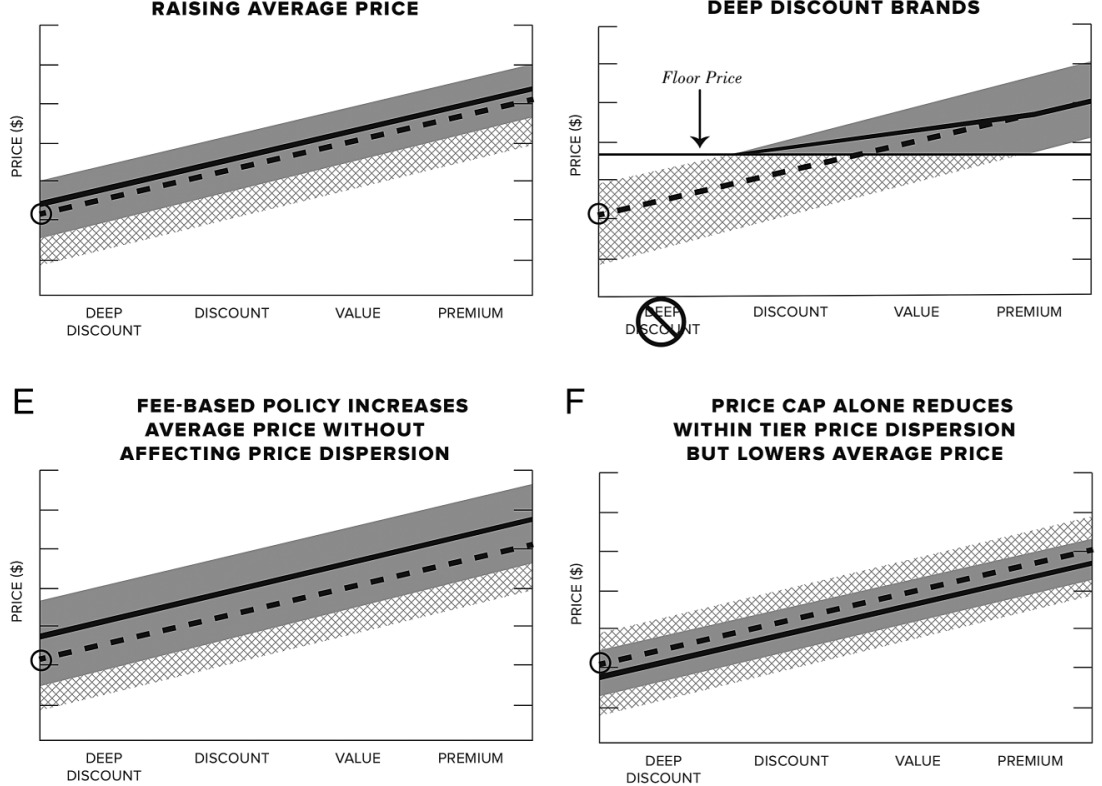

F

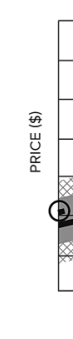

PRICE CAP ALONE REDUCES
WITHIN TIER PRICE DISPERSION BUT LOWERS AVERAGE PRICE

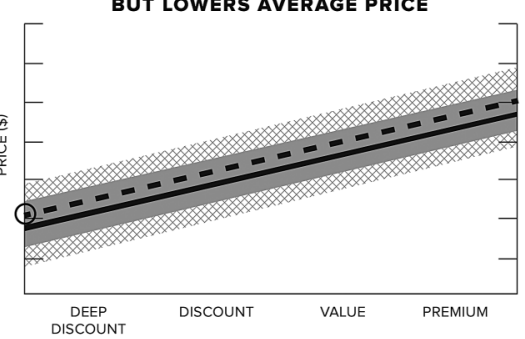

D

D FLOOR MPL + PROMOTIONS BAN REDUCES BETWEEN AND WITHIN TIER PRICE

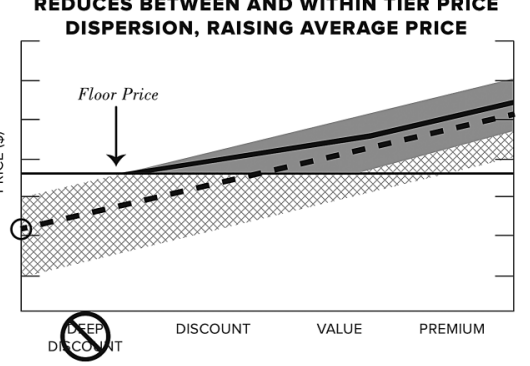

G
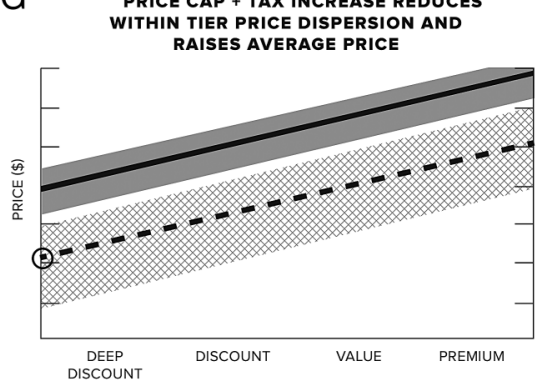

Figure 3 Mechanism through which non-tax policies might increase average tobacco product prices and reduce price dispersion.

the initial average price of cigarettes across a range of price tiers and grey shading surrounding the line illustrates depicts price dispersion (figure 3A). Although the angle of the line, as well as the size and placement of the shading, are hypothesised in the figure, we used the empirical research described above about the proportion of smokers who engage in price minimisation to guide its development. In particular, since fewer than half of smokers report using price promotions, we presume that there are fewer purchases but a larger range of prices below the average than above. The next six panels illustrate potential impacts for each described policy. Price promotion bans reduce price dispersion within price tiers by eliminating the lowest prices, which has the effect of raising average prices (figure $3 \mathrm{~B}$ ). MPLs, when implemented using an inviolable floor structure, might eliminate deep discount brands from the market altogether and slightly raise average prices for middle price tiers whose initial dispersion included below-floor values (figure 3C). In combination with price promotion bans, MPLs also shrink price dispersion within all tiers (figure 3D). Fee policies shift the market upward by the amount of the fee, and therefore only impact average prices (figure 3B). Finally, price caps are designed to shrink industry profits, leaving fewer resources to offset discounts on specific brands or make deep discount brands feasible. ${ }^{54}$ Since they set a cap on what the manufacturer can charge for the product, if implemented alone they may actually lower average prices (figure $3 \mathrm{~F}$ ); to raise average prices, they would need to be accompanied by a tax increase to shifts the market upward (figure 3G).
Despite the potential promise illustrated in figure 3, price promotion bans, MPLs, fee policies and price caps, when implemented in isolation, are not without shortcomings. Although isolated implementation may be necessary where tax hikes are politically challenging, most of these policies will be most effective as complements, rather than substitutes, to excise taxes. Furthermore, each policy design has limitations. MPLs may generate higher profits for retailers or tobacco companies that could be used on other marketing efforts, perhaps undercutting their effect. Promotional bans must be carefully constructed within the context of free speech rules. Fee policies, because they are tied to the real government costs, may only have a modest impact on per unit prices and thus limited influence on smoking behaviour. In addition, the extent to which a retailer licensing fee is passed on to the consumer price of a tobacco product is unclear, so price impacts could be even smaller. The ability of price caps to influence price dispersion presumes diminished profit shifting in the industry. Since most tobacco companies operate in many markets worldwide, they may be able to offset lost profits from price capping policies in single countries with profits generated elsewhere. Finally, some policies that could reduce disparities if they prompt lower income smokers to quit, like floor price policies that eliminate discount brands, could alternatively have a regressive impact if low income smokers switch to higher priced products instead of reducing consumption. Other policies like price promotion bans, however, may be less regressive if the coupon use they eliminate is currently more prevalent for premium brands. ${ }^{29}$ 
In addition, none of the described policies alleviate problems with tax evasion and avoidance. Estimates from the International Tobacco Control (ITC) Policy Evaluation project indicate that in several countries, more than $10 \%$ of consumers recently purchased from a low or untaxed source, whether through legal or illicit means. ${ }^{93}$ These rates grow in places that border low tax areas. ${ }^{94}$ Geographic variation in price policy that produces different prices in neighbouring places, as well as limited resources dedicated to policy enforcement, may facilitate tax avoidance. Unless the price policies described in this review are implemented in a way to reduce this variation (eg, at national levels or simultaneously in neighbouring jurisdictions), they are unlikely to reduce this problem and like tax increases, could increase it. Other tobacco control policies, like enhanced tax stamps, track and trace technologies and licensing laws are likely necessary for all price policies to fulfil their potential. ${ }^{95}$

Our review also unveiled little discussion of promotional bans, MPLs, price caps and fees in reference to non-cigarette tobacco products. Smokeless tobacco products are popular among youth, and prevalence of use exceeds that of cigarettes in many countries, especially in South-East Asia. ${ }^{96}$ In the USA, cigars, little cigars and smokeless products remain an important source of tobacco for many people, with little decline in prevalence in recent years ${ }^{97-100}$ and use of electronic cigarettes is rising, especially among youth. ${ }^{101}$ Pricing policies that apply primarily to cigarettes may create a different type of price dispersion, based not on price tier but on product type, perhaps encouraging price-sensitive consumers to switch or use both cigarettes and other products, instead of quitting altogether. ${ }^{102}$ Although extending tax policies to non-cigarette products can be challenging, due to variations in sizes, packaging and brands, extensions of some non-tax price policies, like price promotion regulations, might be straightforward. Additionally, in places like the US, state and local governments may have more flexibility to regulate pricing and promotions for other tobacco products than they do for cigarettes, due to less pre-emption by federal laws. ${ }^{66}$

Our search has several limitations. Since our search was completed, several major changes have occurred in the tobacco control landscape, including the issuing of the Surgeon General's report of 2014 and the Food and Drug Administration's proposal to extend regulation to more tobacco products in the USA In each of these, federal agencies highlight non-cigarette products, which might have spurred further discussion of them elsewhere in the literature. Although our search terms and strategy resulted in a seemingly comprehensive set of relevant policies, some key literature could have been omitted. We searched for tobacco and cigarette-specific terms rather than product names, anticipating that articles that referred to a particular product, like snus, would also reference tobacco or cigarettes. Our search was also limited to English language articles, and the library used to search grey literature was based in the USA. We may therefore have missed some relevant literature, such as legal commentary, from abroad. Finally, the small number of empirical studies prevented us from conducting meta-analyses or comparing the quality of their approaches. We caution readers to review the methodology of each before extrapolating results more generally.

\section{CONCLUSIONS}

Although increasing tobacco excise taxes is a central tenet of comprehensive tobacco control, ${ }^{103}$ these policies alone may be insufficient for maintaining high prices, or reducing price discrimination, due to industry tactics to keep at least some prices low. ${ }^{50} 104105$ Policies that set pricing floors, limit the ability of the industry to use price variation in marketing and recoup public costs of tobacco use are gaining attention in practice and in the scientific literature. More empirical evaluations are needed to ascertain the extent to which these policies can complement or substitute for excise taxes by generating higher prices, shrinking price dispersion, reducing consumption and ameliorating tobacco-related disparities. A number of articles and reports focused on design and implementation of most non-tax price policies, however, are currently available, and may be valuable to policymakers and tobacco control professionals interested in investigating these options further.

\section{What this paper adds}

- Minimum price laws and restrictions on price promotions are gaining research attention as promising complements to excise taxes.

- Given the paucity of empirical studies, there is limited evidence to date that non-tax policies can successfully raise tobacco prices.

- Most non-tax approaches focus on cigarettes; thus policymakers have an opportunity to apply these policy approaches to non-cigarette tobacco products.

- Policymakers should consult legal assistance to navigate the specific constraints of their regulatory environment when drafting non-tax policies.

Acknowledgements The authors would like to thank Lisa Peterson, M.L.S, California 'Rover' Tobacco Control Library, University of California, Davis for her invaluable assistance in searching the grey literature.

Contributors SDG conducted the search and managed the review process. SDG, MHS and KMR developed an article coding strategy, with input from ECF, AR and TR. SDG and MHS abstracted all data and drafted the manuscript. ECF, AR, TR and KMR provided input into the interpretation and discussion of the results, and edited manuscript drafts. All authors reviewed and approved the final version of the manuscript.

Funding Research reported in this paper was supported by grant number CA154281 from the National Cancer Institute at the National Institutes of Health as part of the ASPiRE study (Advancing Science and Policy in the Retail Environment), and M H Smith's fellowship was supported by grant number 1P50CA180907-01 from the National Cancer Institute and FDA Center for Tobacco Products (CTP). The content is solely the responsibility of the authors and does not necessarily represent the official views of the NIH or the Food and Drug Administration.

Competing interests KMR is a Special Government Employee and member of the Tobacco Products Scientific Advisory Committee for the FDA Center for Tobacco Products - the views expressed in this paper are his and not those of the FDA. KMR has served as an expert consultant in litigation against cigarette manufacturers and Internet tobacco vendors.

Provenance and peer review Not commissioned; externally peer reviewed.

Open Access This is an Open Access article distributed in accordance with the Creative Commons Attribution Non Commercial (CC BY-NC 4.0) license, which permits others to distribute, remix, adapt, build upon this work non-commercially, and license their derivative works on different terms, provided the original work is properly cited and the use is non-commercial. See: http://creativecommons.org/ licenses/by-nc/4.0/

\section{REFERENCES}

1 US Department of Health and Human Services. The Health Consequences of Smoking: 50 Years of Progress. A Report of the Surgeon General. Atlanta, GA: US Department of Health and Human Services, Centers for Disease Control and Prevention, National Center for Chronic Disease Prevention and Health Promotion, Office on Smoking and Health, 2014.

2 Ross $\mathrm{H}$, Blecher E, Yan L, et al. Do cigarette prices motivate smokers to quit? New evidence from the ITC survey. Addiction 2011;106:609-19. 
3 Chaloupka FJ, Straif K, Leon ME. Effectiveness of tax and price policies in tobacco control. Tob Control 2011;20:235-8.

4 World Health Organization. WHO Framework Convention on Tobacco Control. Geneva, Switzerland: World Health Organization, 2003.

5 World Health Organization. WHO technical manual on tobacco tax administration. World Health Organization, 2010.

6 Hill S, Amos A, Clifford D, et al. Impact of tobacco control interventions on socioeconomic inequalities in smoking: review of the evidence. Tob Control 2014;23(e2):e89-97.

7 Brown T, Platt S, Amos A. Equity impact of interventions and policies to reduce smoking in youth: systematic review. Tob Control 2014;23(e2):e98-105.

8 Keeler TE, Hu T-w, Barnett PG, et al. Do cigarette producers price-discriminate by state? An empirical analysis of local cigarette pricing and taxation. I Health Econ 1996; 15:499-512.

9 The International Tobacco Control Policy Evaluation Project. Tobacco price and taxation: ITC cross-country comparison report. 2014.

10 Smith $K E$, Savell $E$, Gilmore $A B$. What is known about tobacco industry efforts to influence tobacco tax? A systematic review of empirical studies. Tob Control 2013;22:144-53.

11 Feighery EC, Ribisl KM, Schleicher NC, et al. How do minimum cigarette price laws affect cigarette prices at the retail level? Tob Control 2005;14: 80-5.

12 Feighery EC, Schleicher NC, Ribisl KM, et al. An examination of the effect on cigarette prices and promotions of Philip Morris USA penalties to stores that sell cigarettes to minors. Tob Control 2009;18:502-4.

13 Orzechowski W, Walker R. The tax burden on tobacco. Historical Compilation 2014. Arlington, VA: Orzechowski and Walker, 2012.

14 Chaloupka FJ, Yurekli A, Fong GT. Tobacco taxes as a tobacco control strategy. Tob Control 2012;21:172-80.

15 Chaloupka FJ, Kostova D, Shang C. Cigarette excise tax structure and cigarette prices: evidence from the global adult tobacco survey and the US National Adult Tobacco Survey. Nicotine Tob Res 2014;16(Suppl 1):S3-9.

16 Institute of Medicine. Ending the tobacco problem: a blueprint for the nation. Washington DC: The National Academies Press, 2007.

17 Stole L. Price discrimination and competition, chapter 34. In: Armstrong M, Porter $\mathrm{R}$, eds. Handbook of industrial organization. Amsterdam: Elsevier North-Holland, 2007:2221-99.

18 Chaloupka FJ, Cummings KM, Morley C, et al. Tax, price and cigarette smoking: evidence from the tobacco documents and implications for tobacco company marketing strategies. Tob Control 2002;11(Suppl 1):i62-72.

19 Feighery EC, Ribisl KM, Schleicher NC, et al. Retailer participation in cigarette company incentive programs is related to increased levels of cigarette advertising and cheaper cigarette prices in stores. Prev Med 2004;38:876-84.

20 Feighery EC, Ribisl KM, Clark Pl, et al. How tobacco companies ensure prime placement of their advertising and products in stores: interviews with retailers about tobacco company incentive programmes. Tob Control 2003;12:184-8.

21 Loomis BR, Farrelly MC, Mann NH. The association of retail promotions for cigarettes with the Master Settlement Agreement, tobacco control programmes and cigarette excise taxes. Tob Control 2006;15:458-63.

22 Brock B, Schillo BA, Moilanen M. Tobacco industry marketing: an analysis of direct mail coupons and giveaways. Tob Control 2015;24:505-8.

23 Pierce JP, Gilmer TP, Lee $\mathrm{L}$, et al. Tobacco industry price-subsidizing promotions may overcome the downward pressure of higher prices on initiation of regular smoking. Health Econ 2005; 14:1061-71.

24 Greenland SJ. Cigarette brand variant portfolio strategy and the use of colour in a darkening market. Tob Control 2015;24(e1):e65-71.

25 Tauras J, Peck R, Chaloupka F. The role of retail prices and promotions in determining cigarette brand market shares. Rev Ind Organ 2006;28:253-84.

26 Federal Trade Commission. Federal Trade Commission cigarette report for 2011. Washington DC, 2013.

27 Gilmore AB, Tavakoly B, Taylor $G$, et al. Understanding tobacco industry pricing strategy and whether it undermines tobacco tax policy: the example of the UK cigarette market. Addiction 2013;108:1317-26.

28 Saenz de Miera Juarez B, Thrasher JF, Reynales Shigematsu LM, et al. Tax, price and cigarette brand preferences: a longitudinal study of adult smokers from the ITC Mexico Survey. Tob Control 2014;23(Suppl 1):i80-5.

29 Cornelius ME, Driezen P, Fong GT, et al. Trends in the use of premium and discount cigarette brands: findings from the ITC US Surveys (2002-2011). Tob Control 2014;23(Suppl 1):i48-53.

30 Nargis N, Fong GT, Chaloupka FJ, et al. The choice of discount brand cigarettes: a comparative analysis of International Tobacco Control surveys in Canada and the USA (2002-2005). Tob Control 2014;23(Suppl 1):i86-96.

31 Dhar SK, Hoch SJ. Price discrimination using in-store merchandising. J Mark 1996;60:17-30.

32 Caraballo RS, Wang $X$, Xu X. Can you refuse these discounts? An evaluation of the use and price discount impact of price-related promotions among US adult smokers by cigarette manufacturers. BMJ Open 2014;4:e004685.
33 Pesko MF, Xu X, Tynan MA, et al. Per-pack price reductions available from different cigarette purchasing strategies: United States, 2009-2010. Prev Med 2014;63:13-19.

34 Cornelius ME, Driezen P, Hyland A, et al. Trends in cigarette pricing and purchasing patterns in a sample of US smokers: findings from the ITC US surveys (2002-2011). Tob Control 2015;24(Suppl 3):iii4-10.

35 Xu X, Malarcher A, O'Halloran A, et al. Does every US smoker bear the same cigarette tax? Addiction 2014;109:1741-9.

36 Choi K, Hennrikus DJ, Forster JL, et al. Receipt and redemption of cigarette coupons, perceptions of cigarette companies and smoking cessation. Tob Control 2013:22:418-22.

37 Licht AS, Hyland AJ, O'connor RJ, et al. Socio-economic variation in price minimizing behaviors: findings from the International Tobacco Control (ITC) Four Country Survey. Int J Environ Res Public Health 2011;8:234-52.

38 Hyland A, Laux FL, Higbee C, et al. Cigarette purchase patterns in four countries and the relationship with cessation: findings from the International Tobacco Control (ITC) Four Country Survey. Tob Control 2006;15(Suppl 3): iii59-64.

39 Ross H, Chaloupka FJ. The effect of cigarette prices on youth smoking. Health Econ 2003;12:217-30.

40 Chaloupka FJ, Wechsler H. Price, tobacco control policies and smoking among young adults. J Health Econ 1997;16:359-73.

41 Farrelly MC, Bray JW, Pechacek T, et al. Response by adults to increases in cigarette prices by sociodemographic characteristics. South Econ J 2001:156-65

42 Azagba S, Sharaf M. Cigarette taxes and smoking participation: evidence from recent tax increases in Canada. Int J Environ Res Public Health 2011; 8:1583-600.

43 Tessman GK, Caraballo RS, Corey CG, et al. Exposure to tobacco coupons among US middle and high school students. Am J Prev Med 2014;47(2, Supplement 1): S61-8.

44 Leatherdale ST, Ahmed R, Barisic A, et al. Cigarette brand preference as a function of price among smoking youths in Canada: are they smoking premium, discount or native brands? Tob Control 2009;18:466-73.

45 Choi K, Hennrikus D, Forster J, et al. Use of price-minimizing strategies by smokers and their effects on subsequent smoking behaviors. Nicotine Tob Res 2012;14:864-70.

46 Patton MQ. Qualitative research and evaluation methods. Thousand Oaks, Calif: Sage Publications, 2002.

47 Warner K, Ernster V, Holbrook J, et al. Public policy on smoking and health: toward a smoke-free generation by the year 2000. A statement of a working group to the Subcommittee on Smoking of the American Heart Association. Circulation 1986;73:381A-95A.

48 Tobacco Control Legal Consortium. Sunshine laws: requiring reporting of tobacco industry price discounting and promotional allowance payments to retailers and wholesalers. 2012.

49 Tobacco Control Legal Consortium. Policy approaches to restricting tobacco product coupons and retail value-added promotions. 2013. http://www. publichealthlawcenter.org/sites/default/files/resources/ tclc-guide-policy-approaches-pricing-cppw-2013.pdf (accessed July 2015)

50 Public Health Policy Change Webinar Series. Policy options for combating tobacco industry price discounting. Public Health Law Center, 2012.

51 Miura M. Regulating tobacco product pricing: guidelines for state and local governments. Tobacco Control Legal Consortium, 2010

52 Tobacco Control Legal Consortium. Cigarette Minimum Price Laws. 2011. http:/l www.publichealthlawcenter.org/sites/default/files/resources/ tclc-guide-cigminimumpricelaws-2011.pdf (accessed July 2015)

53 Berman M, Snyder KM. Tobacco price promotion: policy responses to industry price manipulation. Center for Public Health and Tobacco Policy, 2011.

54 Gilmore AB, Branston JR, Sweanor D. The case for OFSMOKE: how tobacco price regulation is needed to promote the health of markets, government revenue and the public. Tob Control 2010;19:423-30.

55 Smith EA, Blackman VS, Malone RE. Death at a discount: how the tobacco industry thwarted tobacco control policies in US military commissaries. Tob Control 2007:16:38-46.

56 Burton S, Williams K, Fry R, et al. Marketing cigarettes when all else is unavailable: evidence of discounting in price-sensitive neighbourhoods. Tob Control 2014;23(e1):e24-9.

57 Sorg A, Walsh $\mathrm{H}$, Jones J, et al. Regulating Price Discounting in Providence, $R$ Innovative Point-of-Sale Policies: Case Study \#1. St Louis, MO: Center for Public Health Systems Science, George Warren Brown School of Social Work at Washington University, 2013.

58 Center for Public Health Systems Science, George Warren Brown School of Social Work, Tobacco Control Legal Consortium. Pricing policy: a Tobacco control guide. St. Louis, MO: Center for Public Health Systems Science, 2014

59 Willemsen MC, De Zwart WM. The effectiveness of policy and health education strategies for reducing adolescent smoking: a review of the evidence. J Adolesc 1999:22:587-99. 
60 Gallus S, Tramacere I, Zuccaro P, et al. Attitudes and perceptions towards increasing cigarette price: a population-based survey in Italy. Prev Med 2008;47:454-5.

61 Crawford MA, Balch GI, Mermelstein R, et al. Responses to tobacco control policies among youth. Tob Control 2002;11:14-19.

62 Tobacco Technical Assistance Consortium.Addressing Tobacco Pricing Policies: A Toolkit for Tobacco Control Program Managers. 2011. http://www.ttac.org/services/ pricing_strategies/ (accessed July 2015)

63 Ribisl KM, Rogers T, Mahoney M. Assessing Alternative Tobacco Price Policy Options: CPPW Annual Training - March 29, 2011. 2011. http://countertobacco. org/sites/default/files/Asessing \%20Alternative $\% 20$ Tobacco $\% 20$ Price $\% 20$ Policy $\%$ 200ptions\%20-\%20CPPW\%20Annual\%20Training\%202011\%20-\%20Ribis1\%2C $\% 20$ Rogers\%20Mahoney.pdf (accessed July 2015)

64 Schneider JE, Decker CS, Doyle A, Meinders K, Kiss N. Estimates of the costs of tobacco litter in San Francisco and Calculations of maximum permissible per-pack fees. Health Economics Consulting Group LLC. 2009. http://www. greencitiescalifornia.org/assets/waste/SF_cigarette-litter_Tobacco-Litter-Study.doc (accessed July 2015)

65 Chapman S, Freeman B. Regulating the tobacco retail environment: beyond reducing sales to minors. Tob Control 2009;18:496-501.

66 Freiberg M. Options for state and local governments to regulate non-cigarette tobacco products. Ann Health Law 2012;21:407-45, 5 p preceding i.

67 World Health Organization Framework Convention on Tobacco Control Conference of the Parties. Guidelines for implementation of Article 13 of the WHO Framework Convention on Tobacco Control (Tobacco advertising, promotion and sponsorship). Framework Convention on Tobacco Control Conference of the Parties. 2008. http://www.who.int/fctc/guidelines/article_13.pdf?ua=1 (accessed July 2015)

68 Kasza KA, Hyland AJ, Brown A, et al. The effectiveness of tobacco marketing regulations on reducing smokers' exposure to advertising and promotion: findings from the International Tobacco Control (ITC) Four Country Survey. Int J Environ Res Public Health 2011;8:321-40.

69 Giskes K, Kunst AE, Ariza C, et al. Applying an equity lens to tobacco-control policies and their uptake in six Western-European countries. J Public Health Policy 2007;28:261-80.

70 Henriksen L. Comprehensive tobacco marketing restrictions: promotion, packaging, price and place. Tob Control 2012;21:147-53.

71 Loubeau PR. The challenges of tobacco control in Romania. Policy review. Cent Eur J Public Health 2013;21:98-103.

72 Nagler RH, Viswanath K. Implementation and research priorities for FCTC Articles 13 and 16: tobacco advertising, promotion, and sponsorship and sales to and by minors. Nicotine Tob Res 2013;15:832-46.

73 Harris F, MacKintosh AM, Anderson S, et al. Effects of the 2003 advertising/ promotion ban in the United Kingdom on awareness of tobacco marketing: findings from the International Tobacco Control (ITC) Four Country Survey. Tob Control 2006;15(Suppl 3):iii26-33.

74 Yong $\mathrm{H}-\mathrm{H}$, Borland $\mathrm{R}$, Hammond $\mathrm{D}$, et al. Levels and correlates of awareness of tobacco promotional activities among adult smokers in Malaysia and Thailand: findings from the International Tobacco Control Southeast Asia (ITC-SEA) Survey. Tob Control 2008; 17:46-52.

75 Moodie C, Hastings GB. Making the pack the hero, tobacco industry response to marketing restrictions in the UK: findings from a long-term audit. Int J Ment Health Addict 2011;9:24-38.

76 Pearson A, Hoefges M, Lange T, et al. Regulating Tobacco product advertising and promotions in the retail environment: a roadmap for states and localities, J Law Med Ethics 2015. In Press.

77 The Center for Tobacco Policy and Organizing A. Local Tobacco policies in the retail environment. American Lung Association in California: California Department of Public Health, 2013.

78 Dachille K. Regulating Tobacco advertising and promotion: "a commerce clause" overview for state and local governments. Tobacco Control Legal Consortium, 2010.

79 Tobacco Control Legal Consortium. Tobacco Coupon Regulations and Sampling Restrictions. 2011. http://publichealthlawcenter.org/sites/default/files/resources/ tclc-guide-tobcouponregsandsampling-2011.pdf ( July 2015)

80 Public Health Law Center at William Mitchell College of Law. Prohibiting Tobacco Product Coupon Redemption: Sample Language to Amend Existing Minnesota Tobacco Licensing Ordinances. 2011. http://countertobacco.org/sites/default/files/lz/ Restricting\%20Coupon\%20Redemption\%20in\%20Minnesota\%20Final.pdf (accessed July 2015)

81 Rabin RL. Controlling the retail sales environment: access, advertising, and promotional activities. In: Bonnie RJ, Stratton K, Wallace RB, eds. Ending the tobacco problem: a blueprint for the nation. Washington DC: National Academies Press, 2007:641-52

82 Centers for Disease Control and Prevention. State cigarette minimum price laws-United States, 2009. MMWR Morb Mortal Wkly Rep 2010;59:389-92.

83 Tynan MA, Ribisl KM, Loomis BR. Impact of cigarette minimum price laws on the retail price of cigarettes in the USA. Tob Control 2013;22(e1):e78-85.

84 Center for Public Health and Tobacco Policy. Just the Facts: New York Cigarette Marketing Standards Act. 2012. http://www.tobaccopolicycenter.org/documents/ CMSA\%20Fact\%20Sheet.pdf (accessed July 2015)

85 Joint Legislative Committee on Performance Evaluation and Expenditure Review (PEER). A Review of the Department of Revenue's Enforcement of Mississippi's "Unfair Cigarette Sales Law". 2010. http://www.peer.state.ms.us/reports/rpt541. pdf (accessed July 2105)

86 Chaloupka FJ. Commentary on Ross, et al. (2011): beyond cigarette taxes-the need for research on other cigarette pricing policies. Addiction 2011;106:620-1.

87 Feighery E, Rogers T, Ribisl K. Tobacco retail price manipulation policy strategy summit proceedings. Sacramento, CA: California Department of Public Health, California Tobacco Control Program, 2009.

88 Michael J. The Unfair Cigarette Sales Act. St Paul, Minnesota: Minnesota House of Representatives, Research Department, September 2000. http://www.leg.state.mn. us/docs/pre2003/other/000646.pdf (accessed July 2015)

89 Tobacco Control Legal Consortium. Policy tools for minimizing public health and environmental effects of cigarette waste: tips and tools. 2014. http:// publichealthlawcenter.org/sites/default/files/resources/ tclc-guide-cigarette-waste-2014.pdf (accessed July 2015)

90 Schneider JE, Peterson NA, Kiss N, et al. Tobacco litter costs and public policy: a framework and methodology for considering the use of fees to offset abatement costs. Tob Control 2011;20(Suppl 1):i36-41.

91 Branston JR, Gilmore AB. The case for Ofsmoke: the potential for price cap regulation of tobacco to raise pound500 million per year in the UK. Tob Control 2014;23:45-50.

92 de Ojeda A, Barnoya J, Thrasher JF. Availability and costs of single cigarettes in Guatemala. Nicotine Tob Res 2013:15:83-7.

93 Guindon GE, Driezen P, Chaloupka FJ, et al. Cigarette tax avoidance and evasion: findings from the International Tobacco Control Policy Evaluation (ITC) Project. Tob Control 2014;23(suppl 1):i13-22.

94 Nagelhout GE, van den Putte B, Allwright S, Socioeconomic and country variations in cross-border cigarette purchasing as tobacco tax avoidance strategy. Findings from the ITC Europe Surveys. Tob Control 2014;23(Suppl 1):i30-8.

95 National Research Council. Understanding the US illicit tobacco market: characteristics, policy context, and lessons from international experiences. Washington DC: The National Academies Press, 2015.

96 National Cancer Institute and Centers for Disease Control and Prevention. Smokeless Tobacco and Public Health: A Global Perspective. Bethesda, MD: US Department of Health and Human Services, Centers for Disease Control and Prevention and National Institutes of Health, National Cancer Institute. NIH Publication No. 14-7983; 2014

97 Arrazola RA, Neff LJ, Kennedy SM, et al. Tobacco use among middle and high school students_-United States, 2013. MMWR Morb Mortal Wkly Rep 2014:63:1021-6.

98 Agaku IT, King BA, Husten CG, et al. Tobacco product use among adults-United States, 2012-2013. MMWR Morb Mortal Wkly Rep 2014;63:542-7.

99 King BA, Tynan MA, Dube SR, et al. Flavored-little-cigar and flavored-cigarette use among U.S. middle and high school students. J Adolesc Health 2014;54:40-6.

100 Delnevo CD, Giovenco DP, Ambrose BK, et al. Preference for flavoured cigar brands among youth, young adults and adults in the USA. Tob Control 2015;24:389-94.

101 Morbidity and Mortality Weekly Report. Notes from the field: electronic cigarette use among middle and high school students-United States, 2011-2012. MMWR Centers for Disease Control Prevention, 2013:729.

102 Da Pra M, Arnade C. Tobacco product demand, cigarette taxes, and market substitution. 2009 Agricultural and Applied Economics Association Annual Meeting; 26-28 July 2009, Milwaukee, Wisconsin, 2009.

103 WHO Report on the Global Tobacco Epidemic, 2008: The MPOWER package. Switzerland, Geneva: World Health Organization, 2008. http://www.who.int/tobacco/ mpower/mpower_report_full_2008.pdf (accessed July 2015)

104 McLaughlin I, Pearson A, Laird-Metke E, et al. Reducing tobacco use and access through strengthened minimum price laws. Am J Public Health 2014;104:1844-50.

105 World Health Organization. WHO report on the global tobacco epidemic, 2013: enforcing bans on tobacco advertising, promotion and sponsorship. World Health Organization, 2013. 